\title{
The earliest immigration of woolly rhinoceros (Coelodonta tologoijensis, Rhinocerotidae, Mammalia) into Europe and its adaptive evolution in Palaearctic cold stage mammal faunas
}

\author{
Ralf-Dietrich Kahlke*, Frédéric Lacombat \\ Senckenberg Research Institute, Research Station of Quaternary Palaeontology Weimar, Am Jakobskirchhof 4, D-99423 Weimar, Germany
}

\section{A R T I C L E I N F O}

\section{Article history:}

Received 20 May 2008

Received in revised form 29 July 2008

Accepted 31 July 2008

\begin{abstract}
A B S T R A C T
The cold adapted larger mammal faunas of Pleistocene Eurasia (the so-called Mammuthus-Coelodonta faunas) were mainly composed of autochthonous Palaearctic elements. Whereas the history of the immigration and evolution of European woolly mammoths has been exhaustively studied, comparable investigations for woolly rhinoceroses are lacking. Referring to the remains of European and Asian Coelodonta in general and the first skull to be found of a European woolly rhinoceros of early Middle Pleistocene age (from Bad Frankenhausen, Germany) in particular, the occurrence, dispersal, morphological evolution and ecological adaptation of early Coelodonta are reviewed.

Coelodonta originated around 2.5 Myr BP north of the Himalayan-Tibetan uplift. The genus was restricted in its range to different types of steppe landscapes of continental Asia for more than two million years and it wasn't until MIS 12, when extended phases of low temperature and aridity prevailed in western Eurasia that woolly rhinoceroses comparable to Coelodonta tologoijensis spread westward towards Central Europe for the first time. Coelodonta entered Central and, in several cases, Western Europe during all of the subsequent Middle to Late Pleistocene cold stages. Morphological evolution, in particular, the elongation and narrowing of the head and successively its lower and more inclined posture, the shift of the orbits towards the rear of the skull, and changes in the position and morphology of the tooth row concurrently indicate progressive adaptations to an efficient grazer. During the course of their Plio-/ Pleistocene evolution, Coelodonta rhinoceroses changed strikingly from cursorial mixed feeders of central Asian origin to graviportal, highly specialised grazers, inhabiting huge belts of tundra-steppe-like environments during dry and cool to cold periods, and thus becoming the only rhinocerotid to join the Eurasian mammoth faunas. The Bad Frankenhausen Coelodonta record dates the initial formation of a pan-Eurasian Mammuthus-Coelodonta faunal complex to about $460 \mathrm{kyr}$ BP.
\end{abstract}

(c) 2008 Elsevier Ltd. All rights reserved.

\section{Introduction}

The cold adapted larger mammal faunas of Pleistocene Eurasia (Mammuthus-Coelodonta faunas) were composed mainly of autochthonous Palaearctic elements (Kahlke, 1999). Most of these species can be traced back to Plio-/Early Pleistocene forms adapted to tundralike biomes within the periglacial areas of northern Asia and Beringia (e.g. musk-ox, Ovibos and reindeer, Rangifer), or to continental Asian steppe or savannah (e.g. saiga antelope, Saiga and woolly rhinoceros, Coelodonta). Late to Epi-Villafranchian (1.8-0.9 Myr) mammalian associations, largely independent and restricted to northern (tundra) and central (steppe) Asia, respectively, are ancestral to the

\footnotetext{
* Corresponding author. Tel.: +49 (0) 364349309 3330; fax: +49 (0) 364349309 3352.

E-mail address: rdkahlke@senckenberg.de (R.-D. Kahlke).
}

"mammoth fauna" of the Old World (Kahlke, 1999, 2006a). This new faunal group, also called the Mammuthus-Coelodonta faunal complex (Kahlke, 1994, 1999), comprises supra-regionally distributed cold resistant mammal faunas. It is in conjunction with the cooling and consequent aridification of great areas of the northern and central Eurasian landmass during the Middle and Late Pleistocene. Cold stages of this time span were characterized by Euro-Asiatic dispersals of uniform larger mammal faunas. The Mammuthus-Coelodonta faunal complex attained its most advanced evolutionary stage during the Weichselian (Devensian, Valdaian, Dalian). At that time its Palaearctic distribution extended over approximately $190^{\circ}$ of longitude and $40^{\circ}$ of latitude (maps in Kahlke, 1999).

Due to their strict association with continental open environments, the presence of Middle to Late Pleistocene members of the genera Mammuthus (Mammuthus trogontherii, Mammuthus primigenius) and Coelodonta indicates cool to cold and dry climatic conditions. The earliest common occurrence of mammoth and 
woolly rhinoceros in Europe marks the initial formation of the panEurasian Mammuthus-Coelodonta faunal complex, which underwent rapid evolution during subsequent cold stages. Whereas the history of the immigration, evolution and distribution of European mammoths is well studied (e.g., Lister et al., 2005 and references therein), exact data on the occurrence, dispersal, morphological evolution and ecological adaptation of early European Coelodonta are lacking so far, due to the scarcity of fossil records.

\section{Phylogeographic origin, appearance and first spread of early Coelodonta}

The oldest remains of members of the genus Coelodonta Bronn, 1831, dated 2.55-2.16 Myr BP, were discovered in loess deposits at Longdan and Shitougu (Gansu, China) in central Asia (Deng, 2002; Qiu et al., 2004) (site map Fig. 1). Specimens of the Longdan Coelodonta nihowanensis (nomen nudum; Kahlke, 1999, p. 44) display a dolichocephalic skull with pronounced occipital elevation, an incompletely ossified nasal septum, absence of incisors and the characteristic dental morphology of members of the genus Coelodonta (Deng, 2006). These cursorial animals were smaller in size than early Middle to Late Pleistocene Coelodonta and possessed extremely slender limbs (Deng, 2006).

Further records of Coelodonta, which have to be assigned to C. nihowanensis, were reported from several Chinese localities dating to 2.4-1.0 Myr, including sites in the Nihewan basin (Hebei; Teilhard de Chardin and Piveteau, 1930; Li, 1984; Zheng and Cai, 1991), Zhoukoudian Locality 13 (Hebei; Teilhard de Chardin and Pei, 1941; Kahlke, 1969), Lingyi (Shanxi; Chow and Chow, 1959) and Gonghe (Qinghai; Chow and Liu, 1959). All these occurrences indicate a phylogeographic origin of Coelodonta in continental areas of Asia north of the Himalayan-Tibetan uplift. The first appearance of Coelodonta correlates with a major pulse of increased aridity in this region, as recorded in aeolian deposits from ca $2.6 \mathrm{Myr}$ onwards (Guo et al., 2002).

A more evolved form, Coelodonta tologoijensis, was described by Belyaeva (in Vangengejm et al., 1966) from the early Middle Pleistocene fossil layer of Tologoj 2.5 on the Selenga River in western Transbaikalia (Buryatia, Russian Federation). The fossils were stratified immediately above the Lower-/Middle Pleistocene (Matuyama/Brunhes) boundary (Alexeeva et al., 2001). Similar remains were later mentioned from the corresponding deposits at Nalaikha near Ulaan Baatar in Mongolia (Zhegallo et al., 1982, p. 137) and Zasukhino 3 in Transbaikalia (Vangengejm et al., 1990, p. 260f.). An isolated find from the earliest Middle Pleistocene layers of the Sergeevo Formation in the Kuznetsk Basin, named C. cf. tologoijensis by Foronova (1999, p. 79, 2001, p. 26), indicates an initial westward expansion of this group of rhinoceroses into south-west Siberia. Although comparable to geochronologically older finds from China in the cursorial features of its slender distal limb bones, $C$. tologoijensis possesses more developed nasal bones, providing a larger area for a stronger nasal horn boss.

Coelodonta probably did not expand into northern Asia before $0.6 \mathrm{Myr}$, as is indicated by the lack of rhinoceros remains in the extended fossil record of the Olyorian mammal age (1.2-0.6 Myr; Sher, 1987; Lister and Sher, 2001). One find from the vicinity of the town of Olekminsk on the Lena River in southern Yakutia may indicate a first dispersal to the north during the early Middle Pleistocene (Vangengejm, 1961; Boeskorov, 2001), but exact data are lacking. Late Middle Pleistocene Coelodonta antiquitatis (Blumenbach, 1799) were distributed from central to north Yakutia and as far as Chukotka (compilation in Boeskorov, 2001).

Unambiguous records of the first appearance of Coelodonta in Europe are known from the early Middle Pleistocene. Several finds of this first "far western" expansion are documented from Romania. Fossils from the sites of Araci-Carieră, Araci-Fintina Fagului,

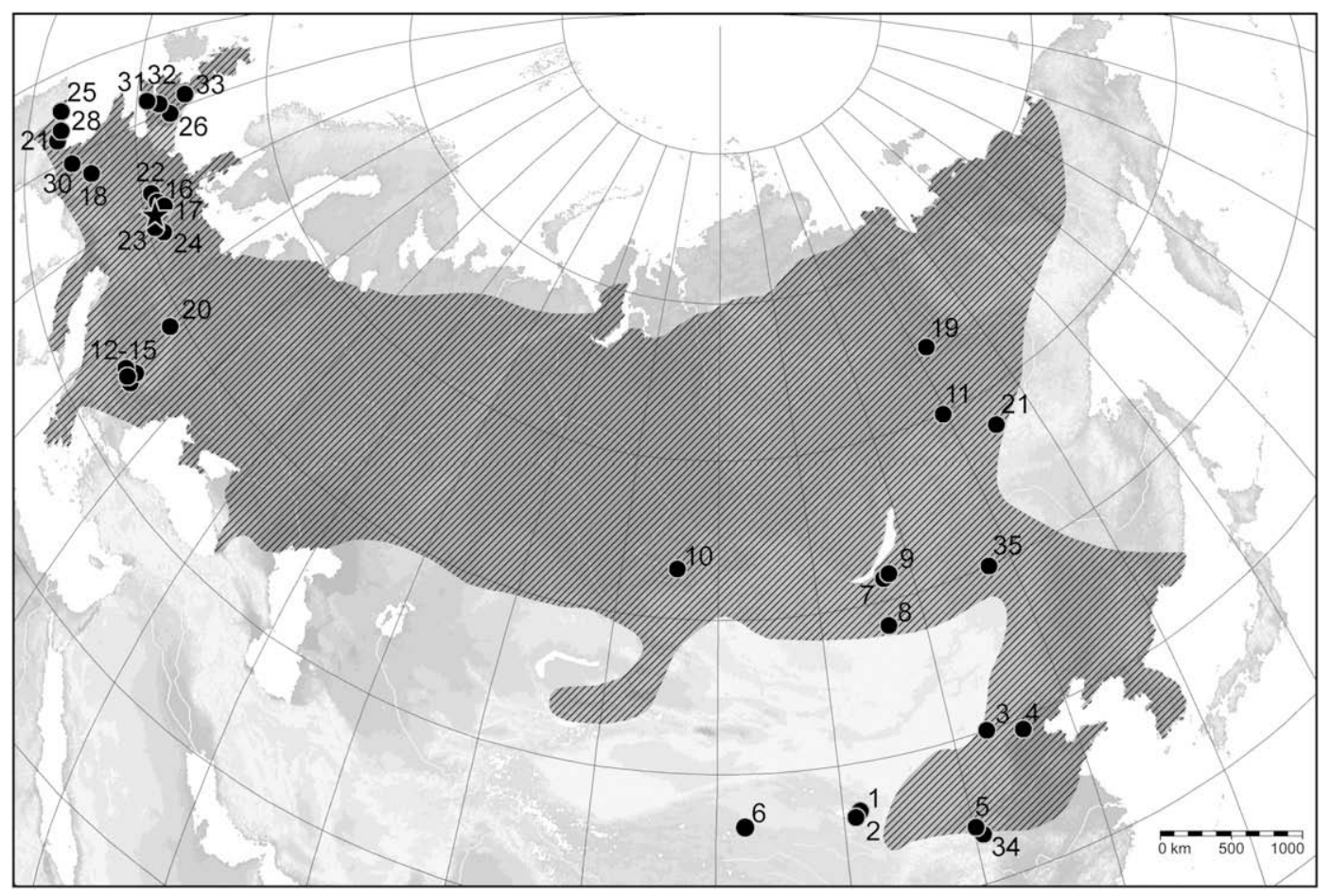

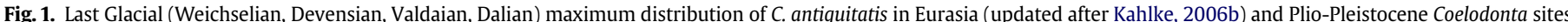

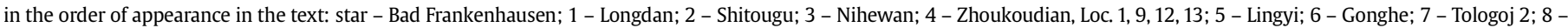

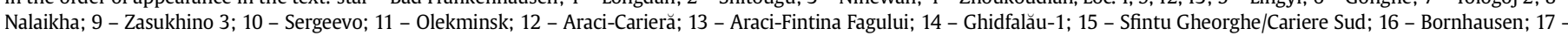

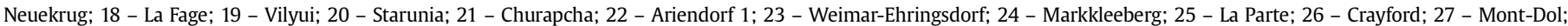
28 - Covacho de Arenillas; 29 - Labeko Koba; 30 - Grotte d’Unikoté; 31 - Hyaena Den; 32 - Sandford Hill; 33 - Pin Hole; 34 - Hsihoutu; 35 - Zhalainoer. 
Ghidfalău-1 and Sfintu Gheorghe/Cariere Sud in the Brasov depression were described as $C$. antiquitatis ssp. (Rădulescu and Samson, 1985 and references therein). Their age of about 460400 kyr (Rădulescu and Samson, 1985, Table 1) corresponds well to the known fossil records of the associated faunal elements, such as giant deer (Megaloceros savini) and Mosbach-horse (Equus cf. mosbachensis).

In addition, records of early Middle Pleistocene Coelodonta are known from Central Germany. Two molars were found in Elsterian gravels at Bornhausen (today called Seesen-Bornhausen), on the north-western margin of the Harz Mountains, Niedersachsen (Sickenberg, 1962, pl. 37). Several isolated finds (fragment of a mandible, five lower teeth, three cervical vertebra) from contemporaneous layers at Neuekrug (today called NeuekrugHahausen) in the same region were mentioned by Bode and Schröder (1913, p. 92f.) but are now lost. A site which has produced outstanding remains of Elsterian Coelodonta is Bad Frankenhausen in northern Thuringia (Germany). The fossils from this site provide, for the first time, information on the appearance of the earliest European woolly rhinoceroses (see Section 4). In sum, at least seven Eastern and Central European sites have provided evidence of the first occurrence of Coelodonta in Europe at about 460-400 kyr (Elsterian, Anglian, Okian).

\section{Palaeogeography, age and fauna of the Bad Frankenhausen Coelodonta site}

The site of Bad Frankenhausen $\left(51^{\circ} 21^{\prime} 10^{\prime \prime} \mathrm{N}, 11^{\circ} 64^{\prime} 23^{\prime \prime} \mathrm{E}\right)$ is located immediately south of the Kyffhäuser Mountains in northern Thuringia (Central Germany), between Rottleben and the town of Bad Frankenhausen, some $46 \mathrm{~km}$ north of the southern limit of the Elsterian glacial maximum and $28 \mathrm{~km}$ south-west of the limit of the Saalian ice sheet (Fig. 2). Around 1900, when gravels of Elsterian age were being extracted in the "Rose" quarry at Bad Frankenhausen, a number of larger mammal fossils were recovered (Staudinger, 1908; Schmidt, 1923). They originate from fore-set beds of a meltwater delta formed in the vicinity of the advancing Elsterian ice sheet (Steinmüller, 1973), which immediately later covered the site. The fossiliferous gravels of Bad Frankenhausen are overlain by varved clays and tills of the Elsterian glaciation (section and lithological analyses in Steinmüller, 1973), providing unambiguous evidence for the occurrence of Coelodonta in Central Europe shortly before the Elsterian glacial maximum. Later advances of the Baltic ice sheet did not reach this region (Fig. 2).
The period of maximum glacial extension of the Elsterian ice advance is assigned by most authors to MIS 12 (Nitychoruk et al., 2006 and references therein), approximately between 427 and 474 kyr BP (Bassinot et al., 1994). The Elsterian ice sheet probably reached its southernmost limit in Europe at around $434 \mathrm{kyr}$ BP (isotopic event 12.2 sensu Bassinot et al., 1994). Since the faunal remains from Bad Frankenhausen have been deposited directly in front of the advancing ice before it reached the position of its maximum extension some $50 \mathrm{~km}$ south and $6 \mathrm{~km}$ west of the site, the first recorded appearance of Coelodonta in Central Europe can be dated to about $460 \mathrm{kyr}$ (isotopic events 12.4-12.3 sensu Bassinot et al., 1994).

The 53 cranial fragments of Coelodonta recovered from the Bad Frankenhausen gravels more than one century ago were recently reconstructed to form an almost intact skull (Fig. 3). In addition to this specimen with its partially preserved upper dentition, several isolated lower premolars and molars of the same individual, a distal part of a left tibia (see Section 4) and a metapodial fragment were identified in the existing collections.

The accompanying fauna from the Elsterian gravels at Bad Frankenhausen comprises bison (Bison sp.), Soergel's ox (Soergelia elisabethae), extinct musk-ox (Praeovibos priscus; type locality), reindeer (Rangifer tarandus ssp.), horse (Equus sp.), steppe mammoth (M. trogontherii) and bear (Ursus sp.) (Staudinger, 1908; Kahlke, 1975a; Fischer, 1985; Crégut-Bonnoure, 2006 and determinations by the authors). The majority of the finds is stored in the Thuringia collection of the Senckenberg Research Station of Quaternary Palaeontology at Weimar (IQW); additional fossils are kept in the Kreisheimatmuseum Bad Frankenhausen (KHBF). All recorded faunal elements indicate that cold, continental climatic conditions and an open environment existed during the formation of the meltwater delta.

\section{The Bad Frankenhausen Coelodonta: a comparison}

The Coelodonta skull from Bad Frankenhausen [IQW 1974/14 011 (Frkhn. 13 965)] belongs to an adult individual and possesses a fragmentary $\mathrm{P}^{2}, \mathrm{P}^{4}-\mathrm{M}^{2} \sin$., and a fragmentary $\mathrm{P}^{3}$ and $\mathrm{M}^{1}-\mathrm{M}^{3}$ dex. (Fig. 3). The lower dentition of the same individual is represented by isolated $\mathrm{P}_{3}-\mathrm{M}_{1}$ sin. [IQW 1974/14 088 (Frkhn. 13 987), IQW 1974/ 14087 (Frkhn. 13 986), IQW 1974/14 086 (Frkhn. 13 985); Fig. 8] and $\mathrm{P}_{4}-\mathrm{M}_{1}$ dex. [IQW 1974/14 089 (Frkhn. 13 988), IQW 1974/14 085 (Frkhn. 13 984)]. The third molar is just being brought into wear, suggesting this individual died at around the onset of sexual

Table 1

Skull dimensions and angles (cf. Fig. 4) of discussed specimens of Plio-/Pleistocene Coelodonta (dimensions in mm)

\begin{tabular}{|c|c|c|c|c|c|c|c|}
\hline \multirow[t]{2}{*}{ Measurements } & \multirow[t]{2}{*}{ Bad Frankenhausen } & \multirow{2}{*}{$\begin{array}{l}\text { Longdan } \\
\text { (Qiu et al., 2004) }\end{array}$} & \multirow{2}{*}{$\begin{array}{l}\text { La Fage } \\
\text { (Guérin, 1973) }\end{array}$} & \multicolumn{4}{|c|}{ C. antiquitatis, Late Pleistocene } \\
\hline & & & & $n$ & Mean & Min. & Max. \\
\hline M1 & 162.50 & 87.00 & 141.00 & 35 & 152.96 & 132.00 & 184.00 \\
\hline M2 & $(256.00)$ & 210.00 & 248.00 & 34 & 277.33 & 247.00 & 316.00 \\
\hline M3 & $(356.00)$ & 350.00 & 340.00 & 32 & 340.20 & 303.00 & 360.00 \\
\hline M4 & 61.20 & - & - & 25 & 64.52 & 52.00 & 83.00 \\
\hline M5 & 83.40 & - & - & 19 & 84.48 & 73.00 & 105.00 \\
\hline M6 & 103.50 & - & - & 23 & 96.65 & 80.00 & 116.00 \\
\hline M7 & 57.50 & - & 65.00 & 38 & 59.60 & 52.00 & 71.00 \\
\hline M8 & 154.00 & 140.00 & 150.00 & 34 & 157.52 & 141.00 & 171.30 \\
\hline M9 & $(514.00)$ & - & - & 27 & 535.00 & 500.00 & 573.00 \\
\hline M10 & $(383.00)$ & - & - & 30 & 358.15 & 338.00 & 390.00 \\
\hline M11 & 785.00 & 770.00 & - & 34 & 775.68 & 655.00 & 872.00 \\
\hline M12 & 184.00 & 140.00 & - & 20 & 192.95 & 164.45 & 237.42 \\
\hline M13 & 55.20 & 30.00 & - & 6 & 74.17 & 60.75 & 92.23 \\
\hline M14 & 124.70 & - & - & 4 & 121.05 & 112.05 & 136.05 \\
\hline M15 & 380.00 & 335.00 & - & 17 & 412.48 & 357.59 & 458.99 \\
\hline A1 & $105^{\circ}$ & - & - & 37 & $125^{\circ}$ & $114^{\circ}$ & $134^{\circ}$ \\
\hline A2 & $110^{\circ}$ & - & - & 38 & $114^{\circ}$ & $100^{\circ}$ & $126^{\circ}$ \\
\hline A3 & $35^{\circ}$ & - & - & 21 & $40^{\circ}$ & $33^{\circ}$ & $48^{\circ}$ \\
\hline
\end{tabular}




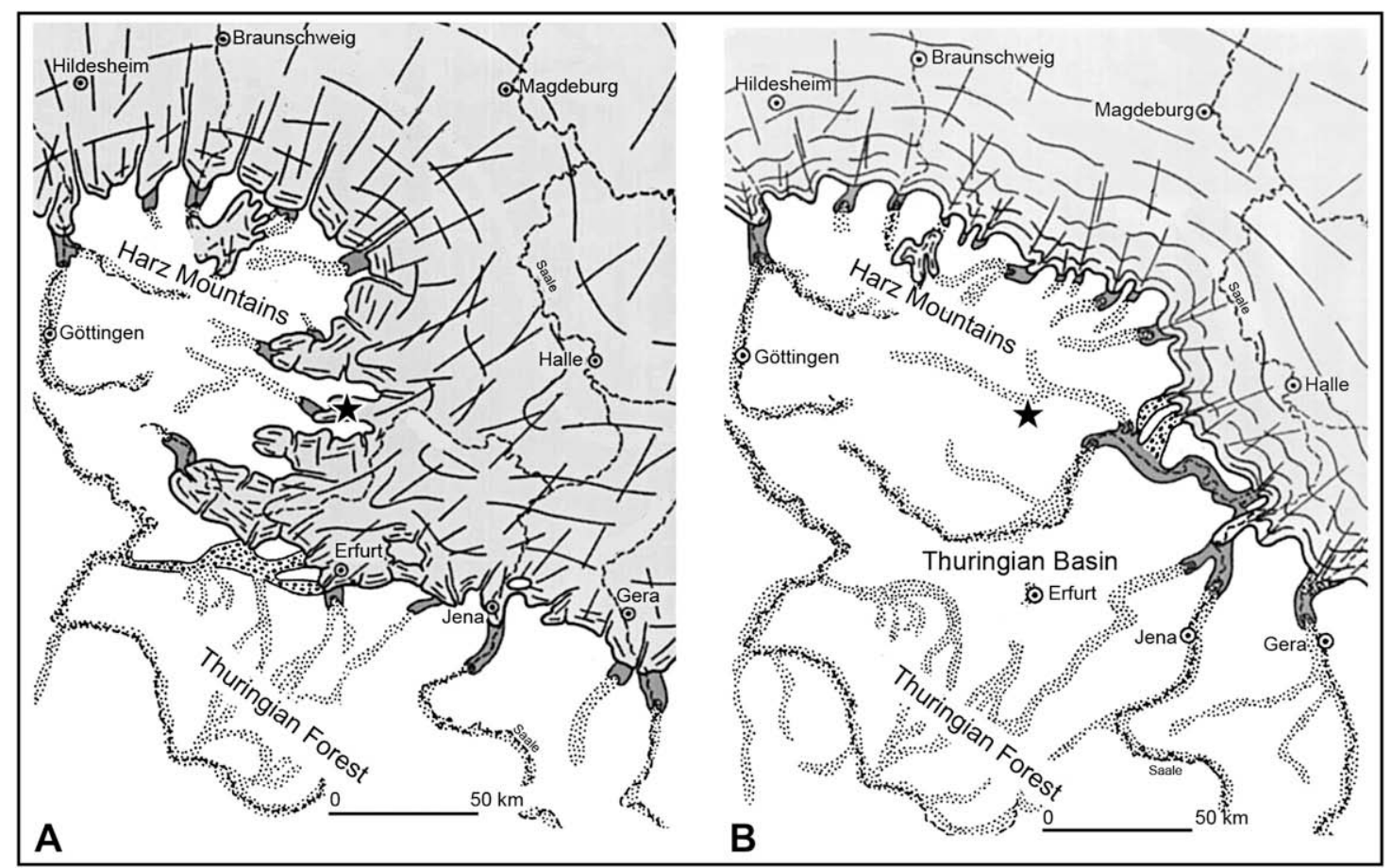

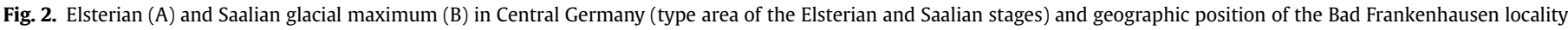
(star). The till covering the site is of Elsterian age and connects the appearance of the earliest European Coelodonta finds to MIS 12 (maps modified after Eissmann, 2002 ).
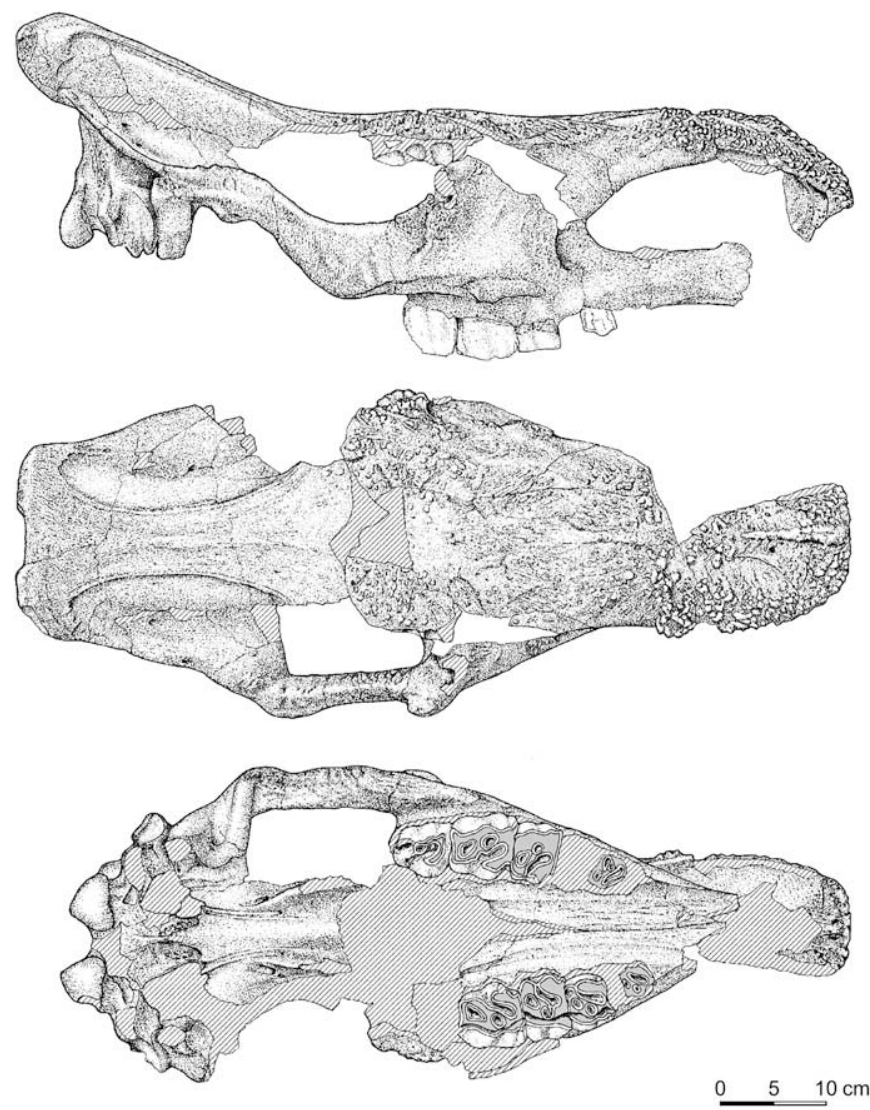

Fig. 3. The skull of early Middle Pleistocene (early Elsterian) C. tologoijensis from Bad Frankenhausen (Thuringia, Germany); illustrating lateral, dorsal and ventral views. maturity, around 10-12 years of age in extant male white rhinoceroses (Hillman-Smith et al., 1986; Zecchini, 1998). The sex of the Bad Frankenhausen rhinoceros cannot be assessed due to the general lack of a comparative series of Coelodonta skulls of late Early to early Middle Pleistocene age. However, the strong rugosity of the nasal (anterior) horn boss and the developed praeorbital tubercle indicate this individual was probably a male (Fig. 3).

The authors studied original $C$. antiquitatis fossils for morphological and biometrical comparisons. The finds studied are stored in the collection of the Zoological Institute of the Russian Academy of Sciences St. Petersburg (abbreviated as ZINRAS; comprising 42 skulls from almost the entire territory of the Russian Federation), in the Thuringia collection of the Senckenberg Research Station of Quaternary Palaeontology at Weimar (fossils from 48 German localities) and in the collection of the French National Museum of Natural History Paris (fossils from 16 localities in France and England). The measurements taken on the crania follow Guérin (1980) and Lacombat (2005) (Fig. 4). The angles proposed by Zeuner (1934) and Loose (1975) were slightly modified so that they could be reproduced on all the skulls studied (Fig. 4).

In comparison to crania of evolved Late Pleistocene C. antiquitatis, the skull from Bad Frankenhausen is short and broad (Table 1). The elevation of the occiput of the Bad Frankenhausen specimen projects backwards above the condyles due to the less obtuse angles between the opisthion and the horizontal $\left(A 1=105^{\circ}\right.$, see Fig. 4, Table 1$)$ and the occipital and the horizontal $\left(A 2=110^{\circ}\right)$. The maximal breadth of the narrow and rounded pentagonal occipital is located just above the condyles (M2, Fig. 4, Table 1), while the minimal breadth corresponds to the strong, narrow and overhanging supraoccipital crest (M14, Table 1). The small width of the occipital gives a general impression of narrowness to the occiput that contrasts significantly with the broader frontal part.

The parietal crests are clearly separated (M13, Table 1). The intact zygomatic arch on the right side of the skull is strongly curved. The anterior rims of the nasal notch and the orbits are located above $\mathrm{P}^{3} / \mathrm{P}^{4}$ and $\mathrm{M}^{2} / \mathrm{M}^{3}$, respectively. The orbits are placed 


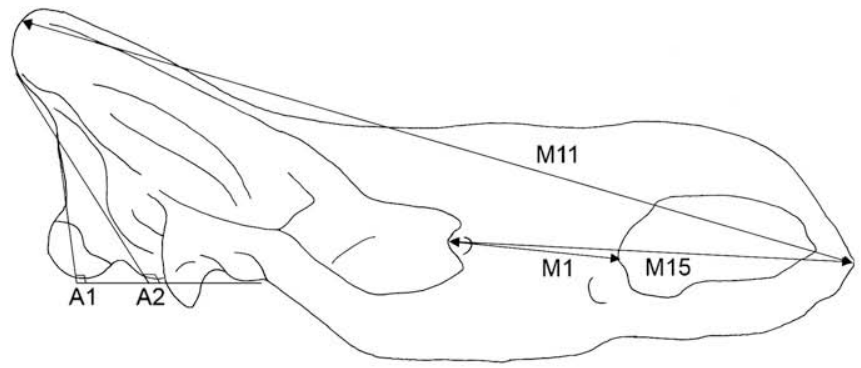

significantly, as illustrated in the increase of the breadth of the palate from $\mathrm{P}^{2} / \mathrm{P}^{3}$ to $\mathrm{P}^{4} / \mathrm{M}^{1}$ and $\mathrm{M}^{2} / \mathrm{M}^{3}$ (M4-6, Table 1 ). In particular, the divergence of the distal part of the tooth row is supported by a corresponding broadening of the skull.

The Coelodonta skull from Bad Frankenhausen also displays archaic features observed in the skull of $C$. nihowanensis from Longdan (see Section 2) figured by Qiu et al. (2004, Pl. 30). These features comprise the maximal breadth (M3, Table 1), the less accentuated occipital inclination, the curvature of the zygomatic arch, the very high position of the orbits (Fig. 5) and the broad frontal horn boss. The reduction of the general breadth of the skull, the increasing occipital inclination (Fig. 6) and the straightening of the zygomatic bones all lead to significantly longer skulls in Late Pleistocene $C$. antiquitatis as well as an upward shift of the more

A
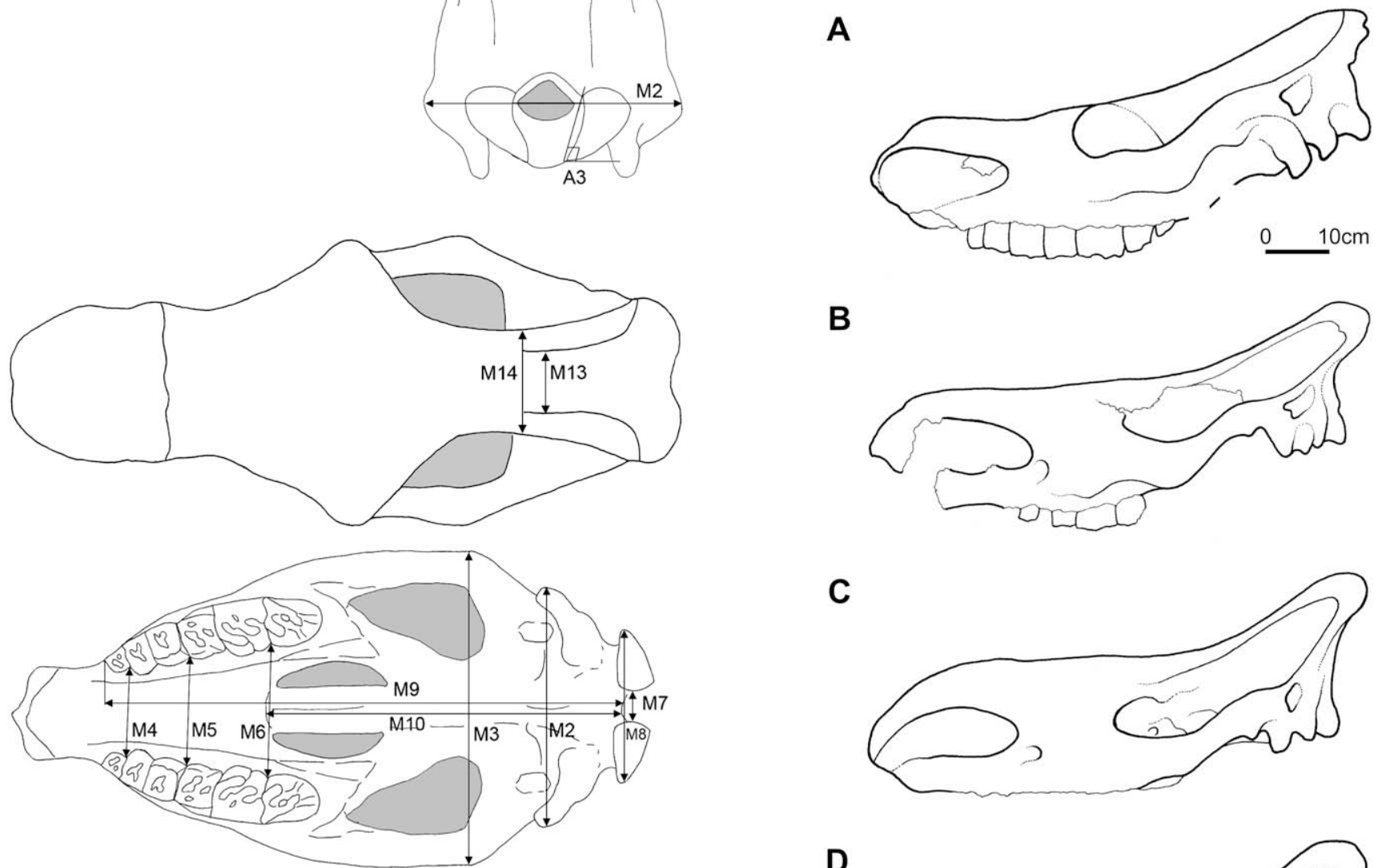

B

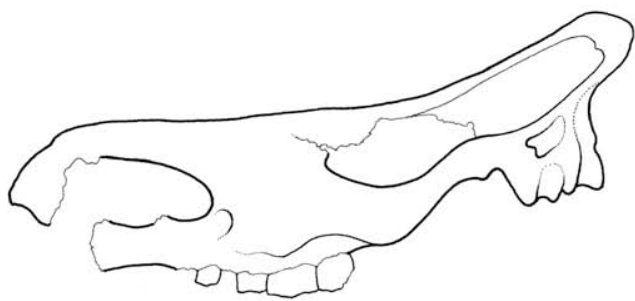

C
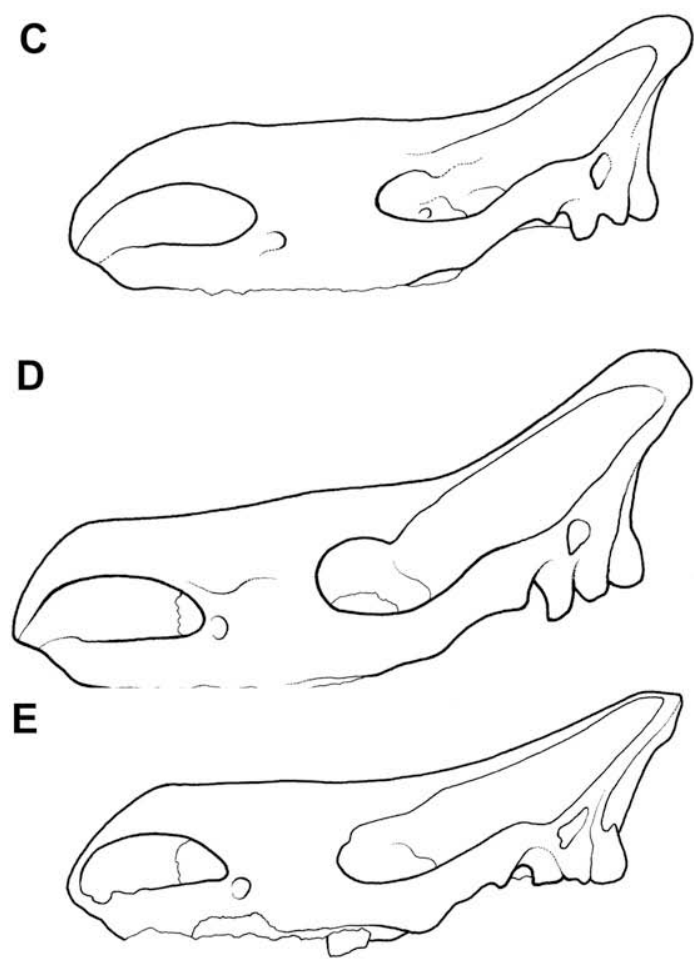

Fig. 4. Skull measurements. A1: opisthion angle; A2: occipital angle; A3: condylar angle; M1: distance orbit-nasal notch; M2: maximum occipital breadth; M3: maximum (zygomatic) breadth of the skull; M4: palatinal breadth between $\mathrm{P}^{2} / \mathrm{P}^{3}$; M5: palatinal breadth between $\mathrm{P}^{4} / \mathrm{M}^{1}$; M6: palatinal breadth between $\mathrm{M}^{2} / \mathrm{M}^{3}$; $\mathrm{M} 7$ : breadth of foramen magnum; M8: breadth at condyles; M9: basal length $\mathrm{P}^{2}-$ basion; M10: length palatine notch - basion; M11: length supraoccipital crest - rhinion; M12: breadth supraoccipital crest; M13: minimal breadth between parietal crests; M14: breadth of the parietals; M15: distance orbit - rhinion.

in a rather elevated position, almost extending to the frontal surface. The extremities of the nasals slope down, implying a strong inclination of the nasal horn boss, which has a regular broad and pronounced ruggedness extending over the whole surface of the bone to the lateral edges. The very broad frontal horn boss extends over the whole width of the frontal bone. The post-palatine notch is located at the level of the $\mathrm{M}^{2}$ (in comparison to the $\mathrm{M}^{3}$ in Late Pleistocene $C$. antiquitatis), a feature linked to the great gap between the palatine notch and the basion (M10, Table 1 ). The posterior part of the Bad Frankenhausen skull is relatively long in comparison to specimens of Late Pleistocene $C$. antiquitatis. The upper cheek tooth rows of the Bad Frankenhausen fossil diverge MV 0980; after Qiu et al. 2004); Middle Pleistocene: B - Bad Frankenhausen [IQW 1974/14 011 (Frkhn. 13 965)]; Late Pleistocene: C - Upper reaches of the Ural ("Yaik") River (ZINRAS 7 849); D - European part of Russia (ZINRAS 10 711); E - Yakutsk area, Yakutia (ZINRAS 10684 ). 


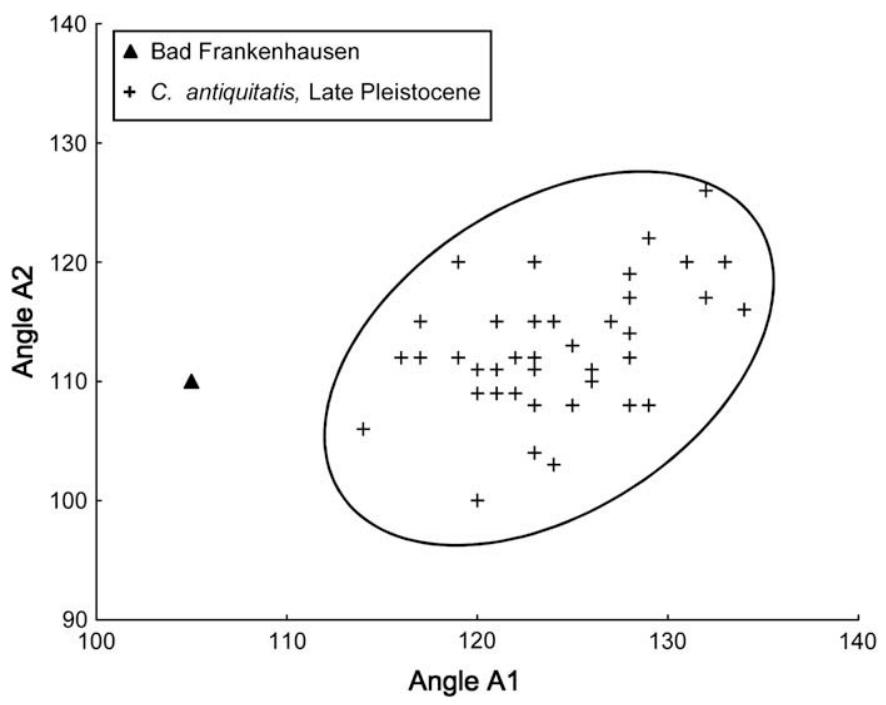

Fig. 6. Comparison of occipital angles of $C$. tologoijensis from Bad Frankenhausen and Eurasian Late Pleistocene C. antiquitatis (authors data; see Section 4).

anteriorly positioned occipital condyles (Figs. 5 and 7, Table 1). Differences in the morphology of the Bad Frankenhausen Coelodonta and $C$. nihowanensis skulls are the narrower and finer nasal extremity and the straight and small but not inclined horn boss of the latter (Fig. 3; cf. Qiu et al., 2004, Pl. 30; Deng, 2006).

The isolated fragment of a skull of Asian C. tologoijensis from Tologoj 2.5 (see section 2) consists of the nasals only (Vangengejm et al., 1966, Fig. 41). Morphologically they are identical with the nasal bones of the Bad Frankenhausen find. The nasals of both specimens have broad, rugose horn bosses whose edges slope down to the same degree. The remaining parts of the nasal septum of the Tologoj specimen display a similar robustness [51 $\mathrm{mm}$ in the Tologoj specimen (Belyaeva in Vangengejm et al., 1966) and $46 \mathrm{~mm}$ in the fossil from Bad Frankenhausen], implying nasal horns comparable in size.

So far only an isolated, partially preserved skull of Coelodonta has been recovered from Middle Pleistocene deposits in Europe.

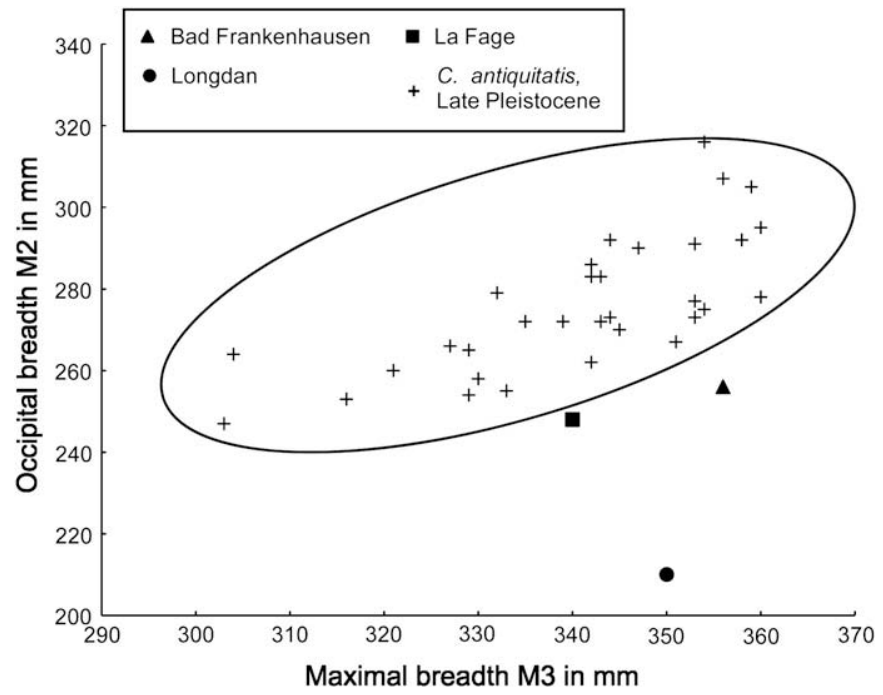

Fig. 7. Comparison of the breadth of skulls of $C$. tologoijensis from Bad Frankenhausen, Pliocene C. nihowanensis from Longdan (data from Qiu et al., 2004), Middle Pleistocene C. antiquitatis praecursor from La Fage (data from Guérin, 1973) and Eurasian Late Pleistocene C. antiquitatis (authors data: see Section 4).
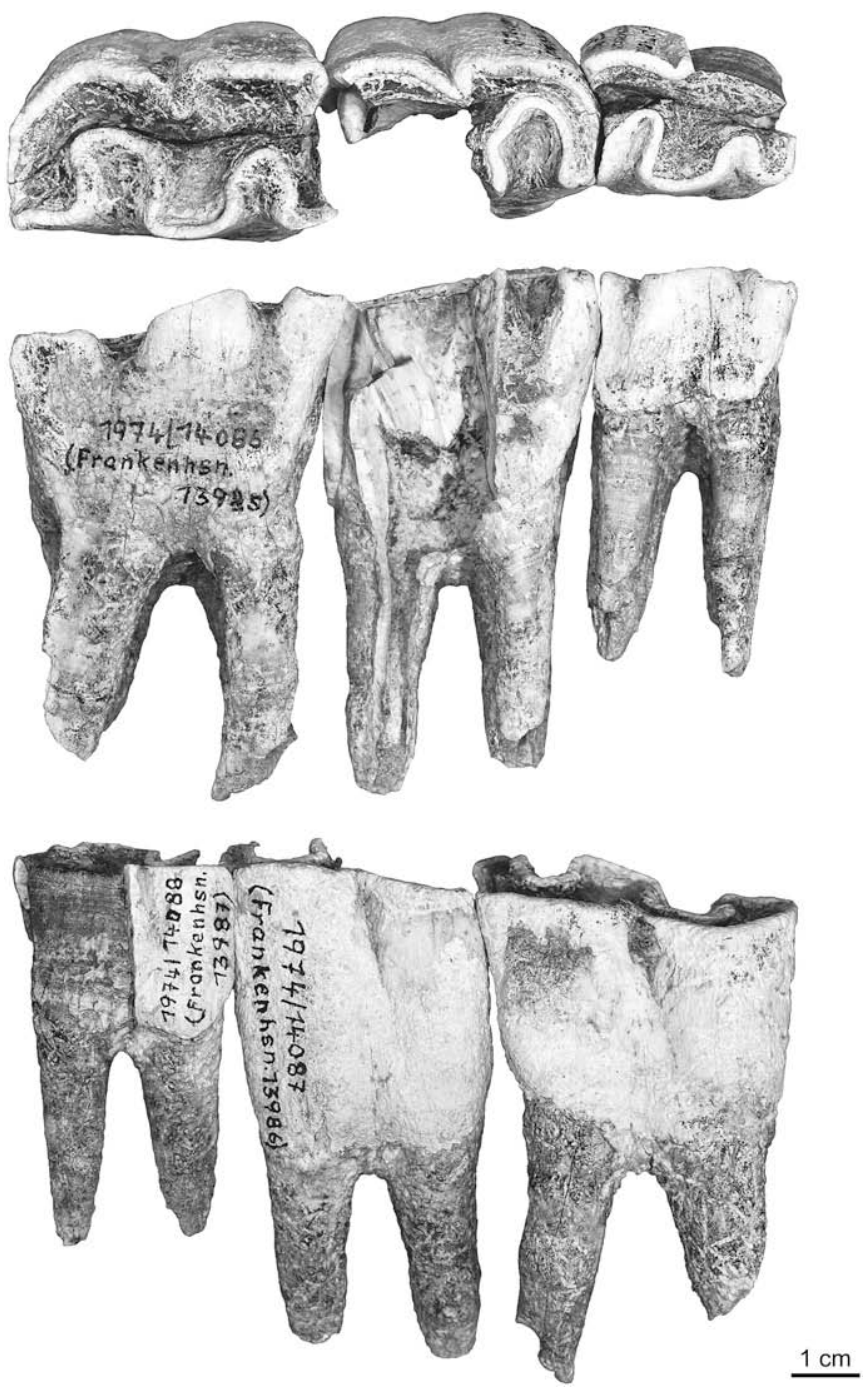

Fig. 8. Left lower tooth row $\left(\mathrm{P}_{3}-\mathrm{M}_{1}\right)$ of early Middle Pleistocene (early Elsterian) C. tologoijensis from Bad Frankenhausen (Thuringia, Germany); illustrating occlusal lingual and buccal views.

The specimen is from La Fage (Corrèze) and was named C. antiquitatis praecursor (holotype) (Guérin, 1973, Pl. 12, 1980, p. 1044). The fossil was recovered from layer 5 at La Fage, which is assigned to MIS 10 or 8 by Maul and Rzebik-Kowalska (1998, p. 94), based on the micromammal record, ${ }^{1}$ and to MIS 8 by Mourer-Chauviré et al. (2003), based on radiochronological data. The morphology of the preserved parts of the La Fage specimen is similar to the Bad Frankenhausen find in the position of the anterior rim of the orbit as well as the palatine and the nasal notches, the form and breadth of the occipital and the curvature of the zygomatic arch.

In evolved Late Pleistocene Coelodonta the anterior orbital rim and the palatine and nasal notches are placed more towards the posterior part of the skull than in the Bad Frankenhausen fossil. Their orbits are located in a much lower position (Fig. 5). The occipital of Late Pleistocene $C$. antiquitatis is broader and more inclined (Figs. 6 and 7), the zygomatic arches are straighter (Fig. 5),

\footnotetext{
1 The size of the M 1 of the water vole Arvicola from La Fage (mean length 3. $58 \mathrm{~mm}$; Chaline, 1972) compares with biostratigraphic data of this genus from samples taken at other European Pleistocene sites dating to the early part of the Saalian, presumably MIS 10 (L.C. Maul, personal communication to the authors 2007-06-01).
} 
the inclination of the nasal horn boss is more pronounced and the nasal septum is more robust than in the geochronologically older forms. The upper tooth rows of the Bad Frankenhausen specimen diverge more than in Late Pleistocene forms. Similarities between the Bad Frankenhausen specimen and evolved $C$. antiquitatis can be found in the separation of the parietal crests and in the distance between orbit and rhinion.

The upper and lower cheek teeth (Figs. 3 and 8) of the Bad Frankenhausen Coelodonta are characterized by a very thin secondary cementum. The medio-fossette of the $\mathrm{M}^{1}$ is open. The ectolophs of the upper teeth undulate, and there is a thin paracone fold separated from the mesostyle by a central notch. A strong protocone constriction is present on the $\mathrm{M}^{3}$. The lower teeth possess V-shaped valleys and relatively flat buccal walls. These features are frequently observed in C. nihowanensis (Qiu et al., 2004; Deng, 2006), C. tologoijensis (Vangengejm et al., 1966) and the Coelodonta specimen from La Fage (Guérin, 1973), but are absent on the teeth of Late Pleistocene $C$. antiquitatis fossils used for comparison. There are no differences in the proportions and size of the teeth (Fig. 9) of the Bad Frankenhausen specimens and those of C. tologoijensis and $C$. antiquitatis praecursor. However, the maxillary teeth of $C$. nihowanensis are smaller and the mandibular teeth are larger. All in all, the teeth of Asian C. tologoijensis and that of the Bad Frankenhausen and La Fage Coelodonta are very similar to each other, but are clearly distinguished from $C$. nihowanensis by their proportions and from Late Pleistocene $C$. antiquitatis by significant morphological differences. In addition, the enamel of the Coelodonta cheek teeth from Bad Frankenhausen is significantly thinner (e.g. $1.97 \mathrm{~mm}$ on the lingual side of the hypocone on the $\mathrm{M}^{1}$ ) than that measured in Late Pleistocene $C$. antiquitatis $(2.37-3.23 \mathrm{~mm}$, $n=21$; measurements taken at the same position on upper first molars in the same stage of wear).

The diaphysis of the isolated and fragmentary Coelodonta tibia from Bad Frankenhausen [KHBF I-692K] is slender. The bone is triangular in section and has a prominent and developed tibial crest, which extends almost to the distal end of the bone, providing a small but broad surface for the fibula. The distal articulation surfaces are shorter, narrower and less oblique than those of C. antiquitatis. There are two distinct articular facets separated by a smooth crest, which transects the distal epiphysis. The slenderness of the tibia emphasizes the cursorial character of the Bad Frankenhausen woolly rhinoceros; the same can be seen in the tibias of $C$. tologoijensis from Tologoj (Vangengejm et al., 1966) and Coelodonta from La Fage (Guérin, 1980; see Section 5). Comparable tibias from the slender-built $C$. nihowanensis have not been recovered so far (Deng T., personal communication, 2007-05-04). The size and morphology of the tibias of Middle Pleistocene Coelodonta differ clearly from robust Late Pleistocene forms (Fig. 10).

\section{Results}

Typical C. tologoijensis from Asia, the Bad Frankenhausen Coelodonta and the European C. antiquitatis praecursor, sensu Guérin (1973, 1980), form a homogenous morphogroup. This group of Coelodonta rhinoceroses has relatively broad skulls with a narrow and slightly obtuse occiput and curved zygomatic arches. The anterior edge of the orbit is located in an elevated and anterior position, and the skulls have very broad nasal and frontal horn bosses. The pronounced divergence of the upper cheek tooth rows corresponds to the general shape of the skull. The limb bones are slender in shape when compared with those of the evolved Late Pleistocene Coelodonta of Eurasia. Slender bones are also characteristic of geochronologically older, more archaic $C$. nihowanensis, but the skull of this species presents specific morphological differences, such as a more or less right-angled occiput (Fig. 5), fused parietal crests and anteriorly narrowing nasals.

Late Pleistocene Eurasian $C$. antiquitatis possess slender and more elongated skulls, occiputs with acute angles and straight zygomatic arches. The orbits are placed towards the rear and sides of the skull, the nasal horn bosses are more inclined anteriorly and the robust nasal septum supported heavier horns. The upper cheek tooth rows are less divergent than in the geochronologically older forms; the limb bones are broader and more robust.

The morphological differences between European Coelodonta from MIS 10 or 8 (La Fage), described as C. antiquitatis praecursor, and evolved $C$. antiquitatis of the Eurasian Late Pleistocene are significant enough to justify a specific rank of the former, i.e. Coelodonta praecursor Guérin, 1980. It is not possible to detect any distinctions between Transbaikalian and Central to Western European forms of Coelodonta, since fossils of Eurasian rhinoceroses

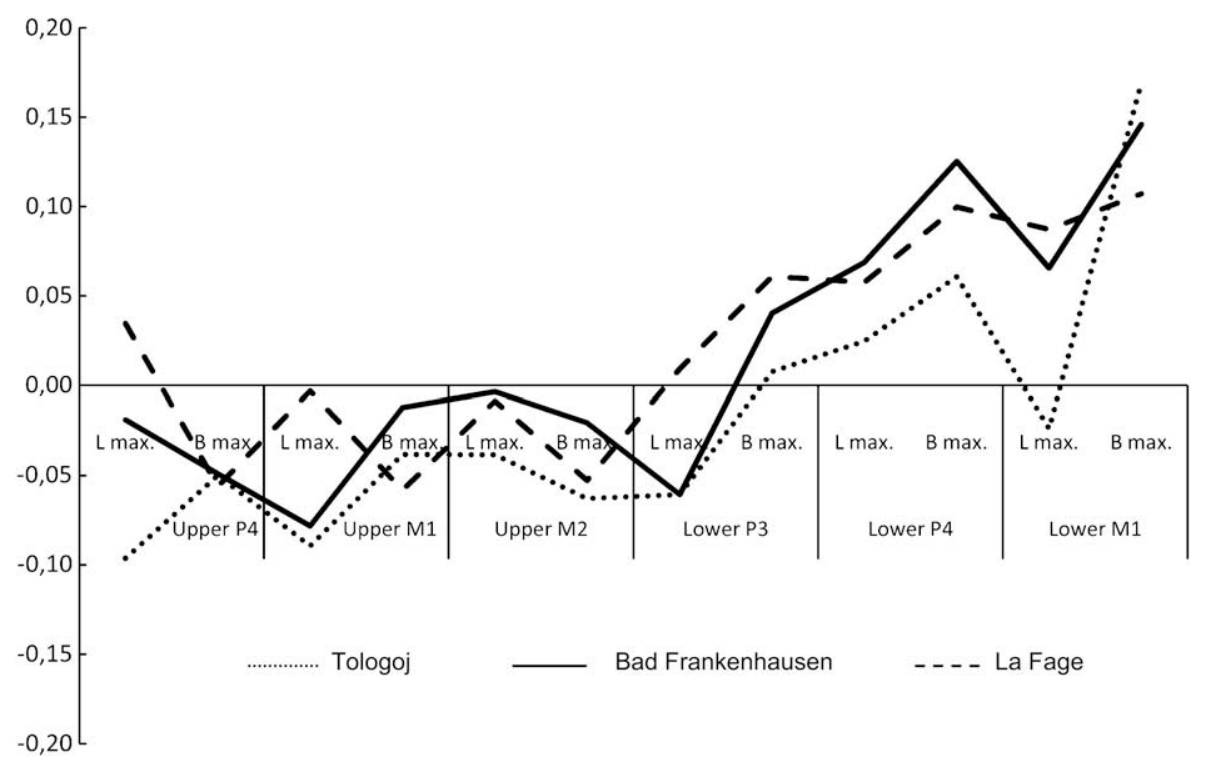

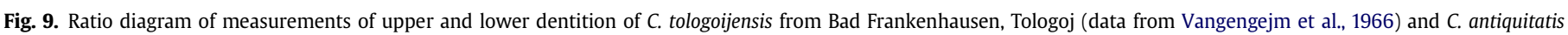

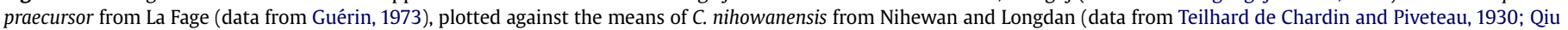
et al., 2004). 


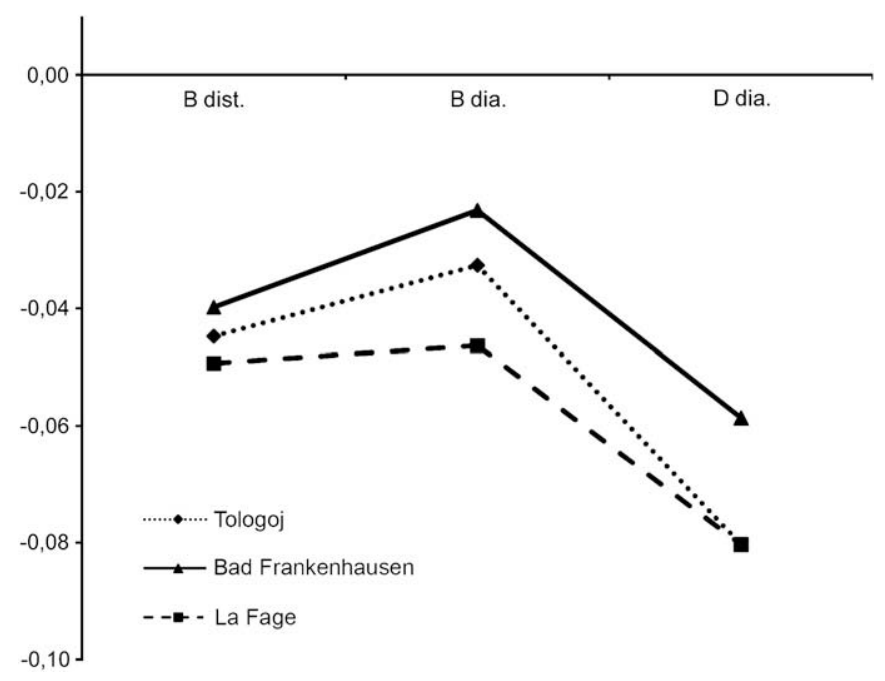

Fig. 10. Ratio diagram of measurements of the tibia of $C$. tologoijensis from Bad Frankenhausen, Tologoj (data from Vangengejm et al., 1966) and C. antiquitatis praecursor from La Fage (data from Guérin, 1973), plotted against the mean of Eurasian Late Pleistocene $C$. antiquitatis (authors data; see Section 4).

dating from the onset of the Middle Pleistocene (Tologoj) and MIS 10 or 8 are rare. Therefore we assign the Bad Frankenhausen woolly rhinoceros finds to C. tologoijensis Vangengejm et al., 1966, which has priority over $C$. praecursor, following the rules of the ICZN. The Bad Frankenhausen find represents the only almost intact skull of Eurasian C. tologoijensis known today.

The group of early Middle Pleistocene tologoijensis rhinoceroses evolved a particular morphology which reflects morpho-functional adaptations to a way of life different to that of Late Pleistocene C. antiquitatis. This is especially evident in the morphology of the skull, which reflects the feeding behaviour of the animals. The straight occiput of the tologoijensis rhinoceroses indicates that these animals carried the head significantly higher than the evolved Coelodonta (Fig. 5). The morphology of the occiput means that the condyles are placed in a more posterior position, so that the atlasaxis vertebral complex is not completely covered by the occipital crest, as in the later forms of Coelodonta. The robust occipital crest of C. antiquitatis indicates the development of strong muscles at the back of the neck, necessary to support the head. However, since the orientation of the foramen magnum did not change, the successive lowering of the position of the skull in the Middle and Late Pleistocene Coelodonta appears to have been achieved by the concurrent lowering of the whole section of the neck.

The progressive lowering of the neck and skull in the Middle to Late Pleistocene Coelodonta was compensated by a shift of the orbits to the back and sides of the skull (Fig. 5). Furthermore, the upper cheek tooth rows became less divergent and the thickness of the enamel and secondary cementum increased. The evolution of cranial and dental morphology of $C$. tologoijensis to $C$. antiquitatis was paralleled by remarkable changes in the general shape of the postcranial skeleton. The cursorial tologoijensis rhinoceroses, characterized by their slender limb bones, evolved into the graviportal Late Pleistocene $C$. antiquitatis.

\section{Discussion}

\subsection{Morphological evolution of Eurasian Coelodonta}

Over the past two million years woolly rhinoceroses have undergone a simultaneous and interrelated morphological change. The general elongation and narrowing of the head, successively its lower and more inclined posture, the shift of the orbits towards the rear of the skull, changes in the position of the cheek tooth rows and the thickening of enamel and secondary cementum all indicate a progressive adaptation of Coelodonta to a very efficient grazer, under increasingly cold climatic conditions.

This interpretation is supported by anatomical features observed in carcasses of Late Pleistocene C. antiquitatis. Muzzles preserved in fragmentary carcasses discovered in 1771 at the Vilyui River (Yakutia; Brandt, 1849), and in the ozokerite deposits of Starunia (Western Ukraine; Bayger et al., 1914, Tab. XXVI, 2-3; Nowak et al., 1930) clearly indicate that Coelodonta possessed rather wide lips, typical of a grazer. The breadth of the opening of the snout of the second woolly rhinoceros from Starunia measured some $35 \mathrm{~cm}$, prior to the body being skinned for conservation (Nowak et al., 1930, p. 27).

It also seems reasonable to explain the size and position of the nasal horn of evolved Coelodonta, observed on remains from several Siberian permafrost sites of Late Pleistocene age (Fortelius, 1983; Chernova et al., 1998; Garutt, 1998), from an adaptive point of view. The tendency of the horn boss to become broader, indicating heavier and longer horns is prevalent during the Middle and Late Pleistocene. Due to the characteristic low posture of the head in evolved C. antiquitatis, the long nasal horn (up to $135 \mathrm{~cm}$; Chernova et al., 1998) was carried more or less horizontally, securely attached at its base on the sloping nasal extremity. In addition to horn's function as a weapon and intraspecific status symbol, it was also a useful tool (Fortelius, 1983). Large areas (several decimeters) of traces of wear, frequently observed on the broader front of the horns, are indicative of regular contact with the ground. The wear surfaces are always divided into a left and a right facet, indicating an alternating movement of the head from one side to the other (Fortelius, 1983). Presumably C. antiquitatis occasionally used its nasal horn while grazing to access low vegetation covered by snow or to free plants frozen to the ground. If such an inference is justified, the position of the nasal horn of evolved Coelodonta is another adaptation to grazing in dry and frosty environments.

The morphological evolution of the head and neck of Coelodonta was also reflected in the vertebral column and the skeleton as a whole. The long spinal processes of the anterior thoracic vertebrae mechanically balanced the low posture of the head with its heavy horns, and probably formed a region where abundant fat accumulated (Kahlke, 1999, pp. 91f.), as observed in Pleistocene Bison and most probably in M. primigenius. Energy-storing "fat humps" are adaptations to seasonally varying conditions. The ecological conditions of open grasslands (tundra-steppe) also led to a general increase in body mass of Coelodonta during the Middle and Late Pleistocene. Several Late Pleistocene finds indicate that C. antiquitatis had long, bristly guard hairs, especially on the neck and shoulders, and a dense, insulating underwool (e.g. Pfizenmayer, 1926, p. 151; Nowak et al., 1930, p. 24). The short hair of the limbs, especially well preserved on the hind legs of the Coelodonta specimen from Churapcha (central Yakutia; Lazarev, 1977), exemplifies an adaptation to habitats where frost was often encountered. It prevented large amounts of snow or ice adhering to the legs and feet, which would have hampered movement (Kahlke, 1999, p. 91).

\subsection{Ecological adaptation of Eurasian Coelodonta}

The earliest member of the woolly rhinoceros group, $C$. nihowanensis, inhabited predominantly steppic areas of central Asia, characterized by shrub and bush vegetation with some patches of woodland (Qiu et al., 2004, p. 192). It was a cursorial mixed feeder with a preference for graze, which inhabited regions from the border of the Tibetan Plateau to eastern China, where continental conditions prevailed (Fig. 1).

Early Middle Pleistocene $C$. tologoijensis continued, most probably, to develop a tendency to graze, as is shown by its 
morphological evolution in comparison to the older Asian forms. According to palaeoenvironmental records obtained from the study of small mammals from Tologoj 2.5 and contemporary Transbaikalian sites, $C$. tologoijensis inhabited meadow to forest steppes, similar to those found in northern Mongolia today, during the early Middle Pleistocene in Asia (Erbaeva and Alexeeva, 2000, p. 72). Toleration to low amounts of precipitation, pronounced seasonality and periodical cold, made Asian C. tologoijensis a potential candidate for dispersal during subsequent glacial periods.

Immediately after the MIS 13/12-(Galerian/Elsterian-)transition, when the Eurasian Stephanorhinus hundsheimensis (Hundsheim rhinoceros) had probably just become extinct, Coelodonta of Asian origin migrated for the first time into Eastern and Central Europe and replaced early Stephanorhinus hemitoechus (steppe rhinoceros). Although both species of Stephanorhinus were mixed feeders and had developed wide, but different, ranges of feeding strategies (Fortelius, 1982; Kaiser and Kahlke, 2005; Lacombat, 2005), they were less specialized in grazing under increasing cold conditions than contemporary Coelodonta when it entered Europe. The MIS 12 (early Elsterian) record of $C$. tologoijensis from the Central European locality of Bad Frankenhausen (see Section 4), dated some $300 \mathrm{kyr}$ younger than the tologoijensis type layer, indicates a progressive adaptation of woolly rhinoceroses to cold stage environments with extensive open landscapes and periglacial conditions.

The ecological evolution of Eurasian Coelodonta towards increasing tolerance of cold stage environments in northern and moderate latitudes was strongly influenced during the last $500 \mathrm{kyr}$ by phases of cooling and aridification recorded during the Middle and Late Pleistocene. During late Middle and Late Pleistocene cold stages, increasingly evolved forms of $C$. antiquitatis - well adapted to the abrasive food resources of the open steppe and to cool to extremely cold environmental conditions - repeatedly spread into Europe. Whereas the Coelodonta site of La Fage (MIS 10 or 8, see Section 4) indicates a steppe environment with some shrub vegetation (e.g. Chaline, 1975), Central European Coelodonta from MIS 8 inhabited the glacial tundra-steppe e.g. at Ariendorf 1 (RhinelandPalatinate; Kolfschoten, 1990, p. 32; Turner et al., 1997, pp. 69ff.), Weimar-Ehringsdorf, basal gravels with Mammal Fauna 1 (Thuringia; Kahlke et al., 2002, p. 163) and Markkleeberg (Saxony; Eissmann, 2002, p. 1307). Glacial tundra-steppe conditions also prevailed during MIS 6, when $C$. antiquitatis entered the Iberian Peninsula for the first time (La Parte, Asturias; Álvarez-Lao and Garcia-Garcia, 2006) and during MIS 3 and 2, when woolly rhinoceroses again advanced westward as far as western France and northern Spain (Kahlke, 1999; Garcia and Arsuaga, 2003, p. 155; Álvarez Lao, 2007).

The range of Coelodonta's ecological tolerance meant that woolly rhinoceroses were present in Central, south-western and north-western Europe even during dryer and cooler periods of MIS 7 and 5, e.g. at Crayford (Kent; Schreve, 2001a, p. 70, 2001b, p. 1702), Weimar-Ehringsdorf, Upper Travertines I and II with Mammal Faunas 7 and 8 (Thuringia; Kahlke, 1975b, p. 383; Kahlke et al., 2002, p. 172), Mont-Dol (Ille-et-Vilaine; Louguet-Lefebvre, 2006), and especially during the cold climatic phases of MIS 3, e.g. at Covacho de Arenillas (Cantabria; Àlvarez Lao, 2007, pp. $321 \mathrm{ff}$.), Labeko Koba (Guipúzcoa; Álvarez Lao, 2007, pp. 321f.), Grotte d'Unikoté (Pyrénées-Atlantiques; Michel, 2005), Hyaena Den and Sandford Hill (Somerset; Currant, 2000, pp. 43f.) and Pin Hole (Derbyshire; Currant and Jacobi, 2001, pp. 1711ff.), as long as the available habitats comprised sufficient amounts of open grassland. The Weichselian (Devensian, Valdaian) habitats of western Palaearctic C. antiquitatis predominantly comprised dry and open cold stage landscapes, and prevailing continental conditions. As members of different mammalian sub-assemblages (detailed in Markova and Puzachenko, 2007), Eurasian C. antiquitatis occupied areas of approximately 23.757 million $\mathrm{km}^{2}$ at that time (Fig. 1).

\section{Conclusions}

Rhinoceroses of the genus Coelodonta originated around $2.5 \mathrm{Myr}$ BP north of the Himalayan-Tibetan uplift (C. nihowanensis). They were cursorial mixed feeders, but preferentially grazed. Around $800 \mathrm{kyr}$ BP a more evolved grazer, $C$. tologoijensis, was a characteristic element of continental Asian faunas of China, Mongolia, Transbaikalia and West Siberia. For more than 2 million years Coelodonta was restricted to different types of steppe landscapes of continental Asia. It was only during MIS 12 when extended phases of low temperatures and aridity in western Eurasia provided the type of conditions which enabled woolly rhinoceroses comparable to C. tologoijensis to spread westward towards Central Europe for the first time. Here it occupied steppic habitats, but also entered areas of tundra-steppe and the periglacial zone of the Elsterian ice advance.

The evolutionary stages of rhinoceroses from Tologoj (C. tologoijensis type site), Bad Frankenhausen, La Fage, and Late Pleistocene $C$. antiquitatis are part of a continuous evolutionary line of Eurasian woolly rhinoceroses. Their adaptation to the cold was influenced by increasingly continental conditions and repeated phases of decreases in temperature. These climatic factors were most pronounced within the huge landmass of central and northern Asia, which therefore has to be regarded as a region of strong evolutive influence on woolly rhinoceroses during the whole Pleistocene period and in particular during the colder phases.

A separate group of little studied, large and slender Coelodonta, which evolved in China from the Late Plio-/Early Pleistocene, survived in more temperate habitats south of areas occupied by C. tologoijensis/antiquitatis, and probably never spread out of this area. The skull from Hsihoutu (Shanxi; Chia and Wang, 1978, pp. 28ff.) of uncertain (? Early Pleistocene) age might belong to a member of this group of lightly built Coelodonta, along with finds described as C. antiquitatis yenshanensis from Zhoukoudian, Loc. 1 (Sinanthropus Site), 9 and 12 (Hebei; Chow, 1978, 1979) and the two skeletons from Zhalainoer in northern Inner Mongolia (Kahlke, 2006b, Fig. 2).

It is highly likely that members of the more robust (northern) C. tologoijensis/antiquitatis evolutionary line entered Central, and in some cases Western Europe, probably during all of the early Middle to Late Pleistocene cold stages (although there are some doubts pertaining to MIS 10, as discussed in Section 4.). These territorial advances were paralleled by changes in the anatomy of the animals resulting in pronounced graviportal locomotion, lowering of the neck and the posture of the head, changes in the shape and proportion of the skull, as well as the dental morphology. The early Middle Pleistocene find of $C$. tologoijensis from Bad Frankenhausen sheds light for the first time on the remarkable morphological evolution that Eurasian woolly rhinoceroses underwent during the following $450 \mathrm{kyr}$ up to the Late Pleistocene, in order to survive as highly specialised grazers in the cold stage landscapes of the Old World.

The progressive adaptation of Middle and Late Pleistocene Coelodonta to decreasing temperatures and increasing continental conditions meant this genus had important advantages over S. hemitoechus, the "steppe rhino" which inhabited relatively dry and open environments in Europe from the "Cromerian" onwards (MIS 15 or 13: Mosbach 2, Hessen; Fortelius et al., 1993; for a discussion of the biostratigraphy see Hemmer et al., 2003). When C. tologoijensis spread for the first time into Eastern and Central Europe (during MIS 12), S. hemitoechus retreated to Western Europe and survived there (e.g. Ensemble III of Tautavel, Pyrénees-Orientales; Moigne et al., 2006). Both species co-occurred at the sites of La Fage (layer 5, MIS 10 or 8) and Weimar-Ehringsdorf (Upper Travertine I and II, MIS 7 or 5). Stratigraphic sequences at the latter site indicate that $S$. hemitoechus was replaced successively by Coelodonta. A similar replacement has been observed in areas of 
Great Britain (MIS 7 and later; e.g. Schreve 2001a, pp. 70f.) and in the northern part of the Iberian Peninsula (MIS 6 and later). During interstadials and especially during periods of interglacial warming the opposite happened: S. hemitoechus prevailed and Coelodonta disappeared from large areas of Europe. However, under optimal climatic conditions even the "steppe rhino" was replaced by the ecologically more demanding S. kirchbergensis.

Over 2.5 Myr Coelodonta evolved from a cursorial mixed feeder of central Asian provenance to a graviportal highly specialised grazer inhabiting huge belts of tundra-steppe environments during cool to cold periods, thus being the only rhinoceros to join the Middle to Late Pleistocene mammoth faunas of Eurasia. The MIS 12 Coelodonta finds from Eastern and Central Europe in general and the record of $C$. tologoijensis from Bad Frankenhausen in particular, dates the initial formation of a pan-Eurasian Mammuthus-Coelodonta faunal complex to about $460 \mathrm{kyr}$ BP (isotopic events 12.4 and 12.3). A more or less uniformly structured, cold adapted larger mammal fauna, comprising elements of arctic as well as central Asian origin, spread for the first time over huge territories of Asia and Europe. As a key member of the Mammuthus-Coelodonta faunal complex, woolly rhinoceroses were one of the most characteristic elements of the progressively evolving Middle and Late Pleistocene cold adapted mammalian faunas of Eurasia.

\section{Acknowledgements}

The study forms part of the Senckenberg Research Institute's project group "Origin, dispersal and impoverishment of Eurasian cold faunas" (R.-D.K.). It was supported by a fellowship of the Alexander von Humboldt-Foundation "Plio-Pleistocene Rhinocerotidae of Central Europe" (F.L.) and by a travel grant of the Deutsche Forschungsgemeinschaft (R.-D.K.), which we gratefully acknowledge. We wish to express our sincere gratitude to persons providing fossil Coelodonta material under their care for comparison, namely G. Baryshnikov and A. Tikhonov (both in St. Petersburg), A. Nadachowski (Cracow) and R. Weinert (Bad Frankenhausen). Our thanks are due to D. Rössler (Weimar) for skilled preparation of the Bad Frankenhausen fossil skull, E. Haase (Weimar) for providing the graphics of Figs. 3 and 5, and T. Korn (Weimar) for taking the photographs used in Fig. 8. Furthermore we are grateful to $\mathrm{H}$. Hemmer (Mainz), E. Markova (Ekaterinburg), P. Martínez-Arbizu (Wilhelmshaven) and L.C. Maul (Weimar) for various information and support. E. Turner (Neuwied) for kindly improving the language of an earlier draft of the manuscript. M. Fortelius (Helsinki) and an anonymous reviewer greatly helped to improve our paper.

\section{References}

Alexeeva, N.V., Erbajeva, M.A., Sen, S., 2001. Geology and fauna, and preliminary correlation of sediments of the main Late Cenozoic sites of the Transbaikal area. Quaternary International 80 and 81, 93-100.

Álvarez Lao, D.J., 2007. Revisión paleontológica de los macromamíferos indicadores de clima frío en la Pleistoceno de la Península Ibérica. Ph.D. thesis, Universidad de Oviedo, Departamento de Geolgiá, Oviedo.

Álvarez-Lao, D., Garcia-Garcia, N., 2006. A new site from the Spanish Middle Pleistocene with cold-resistant faunal elements: La Parte (Asturias, Spain). Quaternary International 142 and 143, 107-118.

Bassinot, F.C., Labeyrie, L.D., Vincent, E., Quidelleur, X., Shackleton, N.J., Lancelot, Y., 1994. The astronomical theory of climate and the age of the Brunhes-Matuyama magnetic reversal. Earth and Planetary Science Letters 126, 91-108.

Bayger, J.A., Hoyer, H., Kiernik, E., Kulczyński, W., Łomnicki, M., Łomnicki, J., Mierzejewski, W., Niezabitowski, E., Raciborski, M., Szafer, W., Schille, F., 1914. Wykopaliska Staruńskie. Słon mamut (Elephas primigenius Blum.). Nosorożec włochaty (Rhinoceros antiquitatis Blum. s. tichorhinus Fisch.). Wraz z współczesna flora i fauna. Nakładem Muzeum imienia Dzieduszyckich, Kraków.

Blumenbach, J.F., 1799. Handbuch der Naturgeschichte, Sechste Auflage. Dieterich, Goettingen.

Bode, A., Schröder, H., 1913. Erläuterungen zur Geologischen Karte von Preußen und benachbarten Bundesstaaten, Lieferung 174. Blatt Lutter am Berge. Gradabteilung 55, No. 6. Königlich Preußische Geologische Landesanstalt, Berlin.
Boeskorov, G., 2001. Woolly rhino (Coelodonta antiquitatis) distribution in Northeast Asia. Deinsea 8, 15-20.

Brandt, J.F., 1849. De Rhinocerotis antiquitatis, seu tichorhini, seu Pallasii structura externa et osteologica observationes, e reliquiis, quae in museis Petropolitanis servantur erutae. Mémoires de L'Académie Impériale des Sciences de SaintPétersbourg, Sixième Serie, Sciences Naturelles 5, 161-416. pl. I-XXV.

Bronn, H.G., 1831. Über die fossilen Zähne eines neuen Geschlechtes aus der Dickhäuter-Ordnung: Coelodonta, Höhlenzahn. Jahrbuch für Mineralogie. Geognosie und Petrefaktenkunde 2, 51-61.

Chaline, J., 1972. Les rongeurs du Pléistocène moyen et supérieur de France. Cahiers de Paléontologie. CNRS, Paris.

Chaline, J., 1975. Les rongeurs, l'âge et la chronologie climatique du remplissage de l'Aven I de la Fage (Corrèze), vol. 3. Nouvelles Archives du Muséum d'Histoire naturelle de, Lyon. 113-117.

Chernova, O.F., Sher, A.V., Garutt, N.V., 1998. Morfologiya rogov sherstistogo nosoroga (Coelodonta antiquitatis). Zoologicheskij Zhurnal 77, 66-79 (in Russian).

Chia, L.-P., Wang, C., 1978. Hsihoutu. A Culture Site of Early Pleistocene in Shansi Province. Wenwu Press, Peking (in Chinese, with English summary).

Chow, B., 1978. The Distribution of Woolly Rhinoceros and Woolly Mammoth Vertebrata Palasiatica 16, 47-59 (in Chinese, with English summary).

Chow, B., 1979. The Fossil Rhinocerotides of Locality 1, Choukoutien. Vertebrata Palasiatica 17, 256-258 (in Chinese, with English summary).

Chow, B.S., Liu, H., 1959. Some Pleistocene Mammalian Fossils from Gunghe, Qinhai. Paleovertebrata et Paleoanthropologica 1, 217-223 (in Chinese).

Chow, M., Chow, B.S., 1959. Villafranchian Mammals from Lingyi, S.W. Shansi. Acta Palaeontologia Sinica 7, 89-97.

Crégut-Bonnoure, E., 2006. European Ovibovini, Ovini and Caprini (Caprinae, Mammalia) from the Plio-Pleistocene: new interpretations. In: Kahlke, R.-D., Maul, L.C., Mazza, P. (Eds.), Late Neogene and Quaternary Biodiversity and Evolution: Regional Developments and Interregional Correlations, vol. 256. Courier Forschungsinstitut Senckenberg, pp. 139-158.

Currant, A., 2000. In: Webster, C.J. (Ed.), The Quaternary Mammal Collections at the Somerset County Museum, Taunton. Somerset Archaeology. Somerset County Council, Taunton, pp. 39-44.

Currant, A., Jacobi, R., 2001. A formal mammalian biostratigraphy for the Late Pleistocene of Britain. Quaternary Science Reviews 20, 1707-1716.

Deng, T., 2002. The earliest known wooly [sic!] rhino discovered in the Linxia basin Gansu Province, China. Geological Bulletin of China 21, 604-608 (in Chinese, with English summary).

Deng, T., 2006. Neogene Rhinoceroses of the Linxia Basin (Gansu, China). In: Kahlke, R.-D. Maul, L.C., Mazza, P. (Eds.), Late Neogene and Quaternary biodiversity and evolution: Regional developments and interregional correlations, vol. 256. Courier Forschungsinstitut Senckenberg, pp. 43-56.

Eissmann, L., 2002. Quaternary geology of Eastern Germany (Saxony, Saxon-Anhalt South Brandenburg, Thüringia), type area of the Elsterian and Saalian Stages in Europe. Quaternary Science Reviews 21, 1275-1346.

Erbaeva, M.A., Alexeeva, N.V., 2000. Pliocene and Pleistocene biostratigraphic succession of Transbaikalia with emphasis on small mammals. Quaternary International 68-71, 67-75.

Fischer, K., 1985. Säugetierfunde aus dem Quartär des Kreises Artern. Beiträge zur Kyffhäuserlandschaft, vol. 9. Veröffentlichungen des Kreisheimatmuseums Bad Frankenhausen. 69-96.

Foronova, I.V., 1999. Quaternary mammals and stratigraphy of the Kuznetsk Basin (South-western Siberia). Anthropozoikum 23, 71-97.

Foronova, I.V., 2001. Chetvertichnye mlekopitayushchie yugo-vostoka Zapadnoj Sibiri (Kuznetskaya kotlovina). Filogeniya, biostratigrafiya, paleoecologiya Transactions of the Russian Academy of Sciences, Siberian Branch, United Institute of Geology, Geophysics and Mineralogy 848, 1-243 (in Russian).

Fortelius, M., 1982. Ecological aspects of dental functional morphology in the PlioPleistocene Rhinoceroses of Europe. In: Kurtén, B. (Ed.), Teeth: Form, Function and Evolution. Columbia University Press, New York, pp. 163-181.

Fortelius, M., 1983. The morphology and paleobiological significance of the horns of Coelodonta antiquitatis (Mammalia: Rhinocerotidae). Journal of Vertebrate Paleontology 3, 125-135.

Fortelius, M., Mazza, P., Sala, B., 1993. Stephanorhinus (Mammalia: Rhinocerotidae) of the western European Pleistocene, with a revision of S. etruscus (Falconer 1868). Palaeontographia Italica 80, 63-155.

Garcia, N., Arsuaga, J.L., 2003. Late Pleistocene cold-resistant faunal complex: Iberian occurrences. In: Ruiz Zapata, M.B., Dorado Valiño, M., Valdeolmillos Rodriguez, A., Gil Garcia, J., Bardaji Azcárate, T., de Bustamante Gutiérrez, I. Mendizábal, Martinez (Eds.), Quaternary climatic changes and environmental crises in the Mediterranean Region. Universidad de Alcalá, Alcalá de Henares, pp. 149-159.

Garutt, N., 1998. Neue Angaben über die Hörner des Fellnashorns Coelodonta antiquitatis. Deinsea 4, 25-39.

Guérin, C., 1973. Les trois espèces de rhinocéros (Mammalia, Perissodactyla) du gisement pléistocène moyen des Abîmes de La Fage (Corrèze), vol. 11. Nouvelles Archives du Muséum d' Histoire naturelle de Lyon. pl. 5-1755-84.

Guérin, C., 1980. Les rhinocéros (Mammalia, Perissodactyla) du Miocène terminal au Pléistocène supérieur en Europe occidentale. Comparaison avec les espèces actuelles. Documents des Laboratoires de Géologie de Lyon 79 (1-3), 1-1185.

Guo, Z.T., Ruddiman, W.F., Hao, Q.Z., Wu, H.B., Qiao, Y.S., Zhu, R.X., Peng, S.Z., Wei, J.J. Yuan, B.Y., Liu, T.S., 2002. Onset of Asian desertification by $22 \mathrm{Myr}$ ago inferred from loess deposits in China. Nature 416, 159-163.

Hemmer, H., Kahlke, R.-D., Keller, T., 2003. Panthera onca gombaszoegensis (Kretzoi, 1938) from the Early Middle Pleistocene Mosbach Sands (Wiesbaden, Hessen, 
Germany) - A contribution to the knowledge of the variability and history of the dispersal of the jaguar. Neues Jahrbuch für Geologie und Paläontologie, Abhandlungen 229, 31-60.

Hillman-Smith, A.K.K., Owen-Smith, N., Anderson, J.L., Hall-Martin, A.J., Selaladi, J.P. 1986. Age estimation of the White rhinoceros (Ceratotherium simum). Journal of Zoology 210, 355-379.

Kahlke, H.-D., 1969. Die Rhinocerotiden-Reste aus den Kiesen von Süßenborn be Weimar. Paläontologische Abhandlungen A 3 (3/4), 667-709. pl. XLVI-XLIX.

Kahlke, H.-D., 1975a. The Macro-faunas of continental Europe during the Middle Pleistocene: stratigraphic sequence and problems of intercorrelation. In: Butzer, K.W., Isaac, G.L. (Eds.), After the Australopithecines. Mouton, The Hague, pp. 309-374.

Kahlke, H.-D., 1975b. Die Rhinocerotiden-Reste aus den Travertinen von WeimarEhringsdorf. Abhandlungen des Zentralen Geologischen Instituts. Paläontologische Abhandlungen 23, 337-397.

Kahlke, R.-D., 1994. Die Entstehungs-, Entwicklungs- und Verbreitungsgeschichte des oberpleistozänen Mammuthus-Coelodonta-Faunenkomplexes in Eurasien (Großsäuger). Abhandlungen der Senckenbergischen naturforschenden Gesellschaft 256, 1-164.

Kahlke, R.-D., 1999. The History of the Origin, Evolution and Dispersal of the Late Pleistocene Mammuthus-Coelodonta Faunal Complex in Eurasia (Large Mammals). Fenske Companies, Rapid City.

Kahlke, R.-D., 2006a. Asiatic Origins of Palaearctic cold adapted larger mamma faunas. International Symposium INQUA Sub-commission Asian Quaternary Stratigraphy, Siberian Branch of the Russian Academy of Sciences "Stratigraphy, paleontology and paleoenvironment of Pliocene-Pleistocene of Transbaikalia and interregional correlations", Ulan-Ude, Russia, p. 47.

Kahlke, R.-D., 2006b. Nashörner der Kältesteppe. Natur und Museum 136, 245-255.

Kahlke, R.-D., Maul, L.C., Meyrick, R.A., Stebich, M., Grasselt, T., 2002. The Quaternary sequence from the late Middle to Upper Pleistocene site of Weimar-Ehringsdorf. In: Meyrick, R.A., Schreve, D.C. (Eds.), The Quaternary of Central Germany (Thuringia \& Surroundings). Field Guide. Quaternary Research Association, London, pp. 163-177.

Kaiser, T.M., Kahlke, R.-D., 2005. The highly flexible feeding strategy of Stephanorhinus etruscus (Falconer, 1859) (Rhinocerotidae, Mammalia) during the early Middle Pleistocene in Central Europe. Berichte des Institutes für Erdwissenschaften, Karl-Franzens-Universität Graz 10, 50-53.

Kolfschoten, T.van, 1990. The evolution of the mammal fauna in the Netherlands and the Middle Rhine area (Western Germany) during the late Middle Pleistocene. Mededelingen Rijks Geologische Dienst 43, 1-69.

Lacombat, F., 2005. Les rhinocéros fossiles des sites préhistoriques de l'Europe méditerranéenne et du Massif Central. Paléontologie et implications biochronologiques. BAR International Series 1419, 1-175.

Lazarev, P.A., 1977. Novaya nakhodka skeleta sherstistogo nosoroga v Yakutii. Trudy Zoologicheskogo Instituta Akademii Nauk SSSR 63, 281-285 (in Russian).

Li, Y., 1984. Fossil mammals and their stratigraphic age from Danangou, Yuxian Co. Hebei Province. Vertebrata Palasiatica 22, 60-68.

Lister, A.M., Sher, A.V., 2001. The origin and evolution of the woolly mammoth. Science 294, 1094-1097.

Lister, A.M., Sher, A.V., Essen, H.v., Wei, G., 2005. The pattern and process of mammoth evolution in Eurasia. Quaternary International 126-128, 49-64.

Loose, H., 1975. Pleistocene Rhinocerotidae of W. Europe with reference to the recent two-horned species of Africa and S.E. Asia. Scripta geologica 33, 1-59.

Louguet-Lefebvre, S., 2006. La population de Mammuthus primigenius du gisement Paléolithique moyen du Mont-Dol (Ille-et-Vilaine, France). Abstract volume. In: Colloque International Q5 «Le Quaternaire, Limites et Spécificités ». Comité National Français de l'INQUA, Association Française pour l'Etude du Quaternaire, Paris, p. 118.

Markova, A. Puzachenko, A. 2007. Late Pleistocene of Northern Asia. In: Elias, S.A. (Ed.), Encyclopedia of Quaternary Science, vol. 4. Elsevier, Amsterdam, pp. 3158-3174.

Maul, L., Rzebik-Kowalska, B., 1998. A record of Macroneomys brachygnathus Fejfar 1966 (Mammalia, Insectivora, Soricidae) in the early Middle Pleistocene (late Biharian) locality of Voigtstedt (Germany) and the history of the genus Macroneomys. Acta zoologica cracoviensia 41, 79-100.

Michel, P., 2005. Un repaire würmien d'hyènes des cavernes: La Grotte d'Unikoté (Iholdy, Pyrénées-Atlantiques, France). Museo de Altamira Monografías 20,131 150

Moigne, A.-M., Palombo, M.-R., Belda, V., Heriech-Briki, D., Kacimi, S., Lacombat, F., Lumley, M.-A.de, Moutoussamy, J., Rivals, F., Quilès, J., Testu, A., 2006. Les faunes de grands mammifères de la Caune de l'Arago (Tautavel) dans le cadre biochronologique des faunes du Pléistocène moyen italien. L’Anthropologie 110, 788-831.

Mourer-Chauviré, C., Philippe, M., Quinif, Y., Chaline, J., Dabard, E., Guérin, C., Hugueney, M., 2003. Position of the palaeontological site Aven I des Abimes de La Fage, at Noailles (Corrèze, France), in the European Pleistocene chronology. Boreas 32, 521-531

Nitychoruk, J., Bińka, K., Ruppert, H., Schneider, J., 2006. Holsteinian Interglacial = Marine Isotope Stage 11? Quaternary Science Reviews 25, 2678-2681.

Nowak, J., Panow, E., Tokarski, J., Szafer, W., Stach, J., 1930. The second woolly Rhinoceros (Coelodonta antiquitatis Blum.) from Starunia, Poland (Geology, Mineralogy, Flora and Fauna). Bulletin International de l'Académie Polonaise des Sciences et des Lettres. In: Classe des Sciences Mathématiques et Naturelles, Série B: Sciences Naturelles, Supplément pl.1-101-47.

Pfizenmayer, E.W., 1926. Mammutleichen und Urwaldmenschen in Nordost-Sibirien. Brockhaus, Leipzig.

Qiu, Z., Deng, T., Wang, B., 2004. Early Pleistocene Mammalian Fauna from Longdan, Dongxiang, Gansu, China. Palaeontologia Sinica 191 (N.S.C 27), 11-198. pl. I-XXXIV.

Rădulescu, C., Samson, P., 1985. Pliocene and Pleistocene mammalian biostratigraphy in southeastern Transylvania (Romania). Travaux de l'Institut de Spéologie «Emile Racovitza» 24, 85-95.

Schmidt, A., 1923. Zur Diluvialgeschichte des Frankenhäuser Tales. Geologisches Archiv 1, 82-101.

Schreve, D., 2001a. Mammalian evidence from Middle Pleistocene fluvial sequences for complex environmental change at the oxygen isotope substage level. Quaternary International 79, 65-74.

Schreve, D., 2001b. Differentiation of the British late Middle Pleistocene interglacials: the evidence from mammalian biostratigraphy. Quaternary Science Reviews 20, 1693-1705.

Sher, A.V., 1987. Olyorian land mammal age of Northeastern Siberia. Palaeontographia Italica $74,97-112$.

Sickenberg, O, 1962. Die Säugetierreste aus den elsterzeitlichen Kiesen (Pleistozän) von Bornhausen am Harz. Geologisches Jahrbuch 79, 707-735.

Staudinger, W., 1908. Praeovibos priscus, nov. gen. et nov. sp., ein Vertreter einer Ovibos nahestehenden Gattung aus dem Pleistocän Thüringens. Centralblatt für Mineralogie, Geologie und Paläontologie 1908, 481-496.

Steinmüller, A., 1973. Die elsterzeitliche Schichtenfolge von Bad Frankenhausen am Kyffhäuser. Zeitschrift für geologische Wissenschaften 1, 1173-1185.

Teilhard de Chardin, P., Pei, W.C., 1941. The Fossil Mammals from Locality 13 of Choukoutien. Palaeontologia Sinica N.S.C 11, 1-106. pl. I-VI.

Teilhard de Chardin, P., Piveteau, J., 1930. Les Mammifères fossiles de Nihowan (Chine). Annales de Paléontologie 19,1-134.

Turner, E., Boenigk, W., Frechen, M., Kolfschoten, M.v., Schnepp, E., Sefkov, E., Steensma, K., 1997. Ariendorf. Quaternary deposits and Palaeolithic excavations in the Karl Schneider gravel pit. Jahrbuch des Römisch-Germanischen Zentralmuseums Mainz 44, 3-191. pl. 1-8.

Vangengejm, E.A., 1961. Paleontologicheskoye obosnovanie stratigrafii antropogenovyh otlozhenij severa Vostochnoj Sibiri. Trudy Geologicheskogo Instituta Akademii Nauk SSSR 48,1-181 (in Russian).

Vangengejm, E.A., Erbaeva, M.A., Sotnikova, M.V., 1990. Pleistocene Mammals from Zasuhino, Western Transbaikalia. Quartärpaläontologie 8, 257-264.

Vangengejm, E.A., Belyaeva, E.I., Garutt, V.E., Dmitrieva, E.I., Zazhigin, V.S., 1966. Mlekopitayushchie eopleistocena zapadnogo Zabaikal'ya. Nauka, Moskva (in Russian).

Zecchini, A., 1998. Le Rhinocéros. Au Nom de la Corne. L'Harmattan, Condésur-Noireau.

Zeuner, F., 1934. Die Beziehungen zwischen Schädelform und Lebensweise bei den rezenten und fossilen Nashörnern. Berichte der Naturforschenden Gesellschaft zu Freiburg i. Br. 34, 21-80.

Zhegallo, V.I., Zazhigin, V.S., Kolosova, G.N., Malaeva, E.M., Murzaeva, V.E., Sotnikova, M.V., Vislobokova, I.A., Dmitrieva, E.D., Dubrovo, I.A., 1982. Nalaikha - opornyj razrez nizhnego plejstotsena Mongolii. In: Nikiforova, K.V. (Ed.), Stratigrafiya i paleogeografiya antropogena. Nauka, Moskva, pp. 124-143 (in Russian).

Zheng, S., Cai, B., 1991. Micromammalian Fossils from Danangou of Yuxian, Hebei. In: Contribution to INQUA XIII. Beijing Scientific and Technological Publishing House, Beijing, pp. 100-131 (in Chinese, with English summary). 